\title{
Reflecting on evaluation practice by considering an educative values- engaged approach: How would it have changed this utilisation-focused evaluation?
}

\section{Jo MacDonald and Roseanna Bourke}

Reflective practice is recognised as one of the four core competency domains for evaluators in Aotearoa New Zealand. This article presents what happens when two theoretical positions or evaluation approaches are juxtaposed to reflect on evaluation practice. Taking a recently completed theory-based, utilisation-focused evaluation of a youth resilience programme piloted nationally, the article considers how an alternative approach — an educative values-engaged theoretical perspective-might have influenced the evaluation. It highlights how these two approaches are enacted in five aspects of evaluation practice: engaging with stakeholders; use of programme theory; generating evaluation questions; methods; and analysis and reporting. The article argues that knowledge of more than one evaluation approach and theoretical perspective expands the evaluation imagination, giving evaluators options and alternatives in evaluation practice. 


\section{Positioning evaluations through a theoretical lens}

The term 'theory' is used in evaluation contexts to refer to diverse bodies of knowledge, encompassing methodological theory, programme theory, social science theory, theory about causality, and theoretical approaches to framing or conducting an evaluation. The last of these is often referred to as evaluation theory (Donaldson \& Lipsey, 2006; Schwandt, 2013). Evaluation theory commonly encompasses prescriptive theories that provide a guiding framework for doing evaluation (Alkin, 2013; Donaldson \& Lipsey, 2006). In this usage, an evaluation theory is synonymous with an evaluation model or an evaluation approach (Alkin, 2013, p. 4).

Reflective practice is recognised as one of the four core competency domains for evaluators in Aotearoa New Zealand (Aotearoa New Zealand Evaluation Association, 2011). Our experience of this domain is that evaluators are more likely to take a reflexive position with regard to the analysis of findings, methods used, and relationships within teams and with stakeholders. However, the theory of practice or evaluation model also needs critique and consideration to allow for innovative evaluation practices to emerge. Donaldson and Lipsey (2006) agree that

many of those participating in evaluation do so within the confines of one theory of practice ... without much apparent reflection or concern about the underpinnings of that theory or the challenges posed by competing theories. (p. 61)

Although we argue that evaluators do not often consider a different theoretical perspective when reflecting on evaluation practice, there are examples in the literature of different evaluation approaches being applied to the same evaluand. Alkin and Christie (2005a) devoted an entire journal to one hypothetical evaluand, where four "actively evaluating theorists" (p. 16) with different theoretical perspectives 
were asked to consider and describe how they would evaluate an education programme. A similar exercise was undertaken as part of an extensive publication on evaluation theory and models (Stufflebeam \& Shinkfield, 2007).

Drawing inspiration from these examples, this article describes a recently completed theory-based (Rogers, 2007; Weiss, 1997), utilisation-focused (Patton, 2013) evaluation and considers how the evaluation might have been portrayed from another theoretical position: an educative values-engaged perspective (Greene, 2013; Greene, DeStefano, Burgon, \& Hall, 2006; Hall, Ahn, \& Greene, 2012). It highlights how these approaches-both themselves hybrids of more than one evaluation theory or model-are enacted in five aspects of evaluation practice: engaging with stakeholders; use of programme theory; generating evaluation questions; methods; and analysis and reporting. Given that each theoretical perspective influences the evaluator's field of vision and "thus entails that certain aspects fall into focus, while others are excluded" (Hansen, 2005, p. 451), it is important to consider what is foregrounded under different evaluation theoretical models. This article concludes by reflecting on whether and how knowledge of different evaluation theories or approaches contributes to evaluation practice.

\section{The evaluand: My FRIENDS Youth Resilience Programme}

The My FRIENDS Youth Resilience Programme (referred to here as My FRIENDS Youth) was trialled in New Zealand secondary schools from 2013 to 2015. This licensed Australian programme is intended to build students' self-esteem and resilience to help them deal with feelings associated with depression and anxiety (Ministry of Health, 2016). It was initiated by the Prime Minister's Youth Mental Health Project and implemented through the Ministry of Education's Positive Behaviour for Learning (PB4L) programme 
(Ministry of Education, 2013). The 10-session programme is based on cognitive behavioural therapy principles and is a universal programme designed to be implemented in a range of settings and applicable for all young people (Barrett, 2012). In New Zealand it was facilitated largely by Health and Physical Education teachers of Year 9 students (aged 13-14) as part of the Health and Physical Education learning area. A total of 26 schools participated in the trial during the 2-year evaluation (MacDonald, Bourke, Berg, \& Burgon, 2015), and a strong student voice component was an integral part of the evaluation (Bourke \& MacDonald, 2016).

\section{The evaluation}

The evaluation of My FRIENDS Youth was commissioned after a government-initiated request for proposals (RFP) process in early 2013. An RFP document can shape an evaluation in terms of focus, scope and priority areas, and this includes prescribing the approach to be taken (Leviton, 2015). In this instance, guidance was given in the RFP about important features of the evaluation, such as the inclusion of pre- and post-programme measures of anxiety and depression, feedback from young people and school staff, and context-based success factors (Ministry of Education, 2013, p. 5).

The New Zealand Council for Educational Research (NZCER), in partnership with Victoria University of Wellington, was contracted to evaluate My FRIENDS Youth. The RFP was initially for the evaluation of a 1-year trial in 10 secondary schools, but in response to changes in the operational policy context this evolved into a 2-year evaluation involving 26 schools. The evaluation was theory-based (Rogers, 2007; Weiss, 1997), and centred strongly around a theory of change that was used "as a framework for determining the variables that should be measured in an evaluation or as a means of better understanding the evaluand" (Davidson, 2000, p. 19). The 
evaluation explored three main focuses: (1) the extent of implementation fidelity by teachers and schools; (2) progress made towards short-term outcomes for students; and (3) the degree of consistency with the New Zealand curriculum framework and our bicultural and multicultural context.

Consistent with a focus in the RFP on the intended use of the evaluation findings, the evaluation plan also framed the evaluation as utilisation-focused (Patton, 2013). In utilisation-focused evaluation, all aspects of an evaluation are thought about in relation to how they will affect use by the "primary intended users" (e.g. Patton, 2008, p. 37), and often result in negotiated approaches to the evaluation. As Patton (2015) points out, "the evaluation facilitator develops a working relationship with intended users to help them determine the kind of evaluation they need" (p. 458), and through this consultation, decisions on conceptual frameworks and methodological approaches are negotiated. These primary intended users are the individuals who will be the "real users of the evaluation" (Christie \& Alkin, 2013, p. 44). They should have both the authority and the willingness to use evaluation findings to inform their decisions or actions (International Development Research Centre, 2012).

In the My FRIENDS Youth evaluation, the primary intended users were designated at the outset as the strategic and operational teams at the Ministry of Education, who intended to use the findings "[to] decide if there are any aspects of this initiative that need strengthening or changing ... [and] to contribute to decisions about the extent of 'scale-up' for this initiative” (NZCER, 2013a, p. 4). Thus, the funders of both the programme and the evaluation were also the primary intended users. The evaluation findings through the final report were published by the funder 1 year after completion of the evaluation to enable other users to access the findings and thus increase the ability for practitioners - such as facilitators, 
teachers and guidance counsellors- to use the results more widely (MacDonald et al., 2015).

Having the client or commissioner of the evaluation as the primary intended user is not a feature of all utilisation-focused evaluations, although it is common in evaluation work for central government agencies. This shapes an evaluation by giving clients — as both funders of the evaluation and primary intended users - substantial input into decisions about who to involve with regard to research design and methods, and reporting (Patton, 2003, 2008). This affords a greater likelihood of the evaluation findings being useful and used by clients.

However, it also requires evaluators to think ethically and be mindful of the wider evaluation context. Positioning the client as the primary intended user brings with it the risk that the evaluation is not seen as credible to others involved in and affected by the evaluation. It may also mean that reporting timelines and access to evaluative information do not take into account other stakeholders' information needs, thus limiting the wider use of the findings. In the My FRIENDS Youth evaluation, other stakeholders (such as the teachers involved in the day-to-day facilitation of the programme in the school context) were identified as 'secondary intended users' but did not contribute to discussions about research design, methods or reporting. They did, however, contribute to facilitating access to the student participants to ensure authentic "student voice", which was a pivotal aspect of the evaluation (Bourke \& MacDonald, 2016).

\section{A brief overview of the educative values-engaged evaluation approach}

The alternative approach considered in this article is the educative values-engaged approach, which "explicitly and intentionally involves descriptions and prescriptions of values" (Hall et al., 2012, p. 196). This approach was selected because it had the potential to be a good 
fit with My FRIENDS Youth's focus on the wellbeing of all students, and the Ministry of Education's interest in context, and outcomes for Māori and Pasifika students. It could therefore have been a realistic alternative.

The educative values-engaged approach draws selectively on three influential evaluation approaches: Stake's responsive evaluation (Stake, 1995, 2008), House and Howe's (1999) deliberative democratic evaluation, and Cronbach's focus on evaluation as an educational endeavour (Cronbach et al., 1980). Three key values prescribed by the educative values-engaged approach are inclusion, equity and diversity (Hall et al., 2012), and these are integral when considering secondary users of an evaluation (i.e. the participants and those who might draw on the evaluation results for their own practice). An educative values-engaged approach to evaluation privileges the inclusion of multiple and diverse stakeholder perspectives, and gaining contextualised knowledge about programmes and how they are experienced in meaningful ways in people's lives (Hall et al., 2012). Drawing on Cronbach, it is also oriented towards being educative - a way for society to learn about itself — rather than having a narrower focus on decision-making and how people will use the information gained from an evaluation (Greene et al., 2006).

\section{Stakeholder engagement}

Stakeholder engagement is addressed in many evaluation theories, but there are substantial differences in who is counted as a stakeholder, and when and how they are included in the evaluation (Alkin \& Christie, 2005b, p. 118). In the My FRIENDS Youth evaluation, as already discussed, Ministry of Education stakeholders were viewed as the primary intended users and a close relationship with key Ministry personnel was seen to be a central factor in ensuring a successful evaluation. The values, priorities and questions of these primary intended users framed the evaluation (Patton, 2003). 
In addition to working at the policy level, the evaluation team also built strong relationships at the operational level of the programme. This involved working with the two regional My FRIENDS Youth facilitators, whose role was to train teachers in the programme and support schools with implementation. These facilitators kept the evaluation team informed of implementation timelines and issues in schools, and supported schools to make sense of student survey data when school-level data from the evaluation were returned to each school. They also contributed to the review of the evaluation report and were eager to make use of the findings at an operational level.

Schools, teachers and students were recognised as stakeholders in the My FRIENDS Youth evaluation plan, and members of the evaluation team attended regional meetings early in the evaluation to explain the evaluation purpose and process. However, apart from one school's involvement in the scoping phase (described below), teachers did not contribute to decision making about the evaluation, and relationships with teachers and students focused on data collection. A summary of the evaluation was written, highlighting findings likely to be of most interest to those facilitating the programme with students, but teachers did not contribute to analytical sense-making.

In contrast, an educative values-engaged approach to evaluation aims to engage with a diverse range of stakeholders, more intentionally and systematically, "paying particular attention to ensuring inclusion of the interests and perspectives of those traditionally underserved" (Greene et al., 2006, p. 60). Bringing this theoretical perspective to the My FRIENDS Youth evaluation, a wider group of stakeholders may have had a much larger role throughout the evaluation. Although in this approach it is not necessary for stakeholders to become co-evaluators (Lopez, 2005), it does allow for the values, priorities and questions of teachers, students and parents to influence the framing of the evaluation, alongside the questions of the 
government stakeholders. In this model, the evaluation team would seek to include a wider group of stakeholders in discussing data and emerging findings at the school and programme level. Two other aspects of evaluation practice where a broader range of stakeholders could be included - the development of a programme theory and the generation of evaluation questions - are discussed next.

\section{Use of programme theory}

Programme theory in evaluation focuses on the evaluand itself rather than evaluation practice (Donaldson \& Lipsey, 2006, p. 64). The use of programme theory - in the form of intervention logics, logic models or theories of change-is a common practice in many evaluation approaches (Rogers, 2007, p. 63). The term 'theory-based evaluation' refers to approaches that make assumptions about how a programme is expected to work and then use this programme theory as a guide for the evaluation, through informing evaluation questions, data collection and analysis (Rogers, Petrosino, Huebner, \& Hacsi, 2000, p. 5). As part of a scoping phase for the My FRIENDS Youth evaluation, evaluators interviewed Ministry of Education stakeholders and three staff from one of the schools trialling the programme. One outcome of this scoping phase was a theory of change, which guided decisions about who was spoken to during the evaluation, and the specific questions developed for the surveys and the qualitative interviews (MacDonald et al., 2015).

This evaluation took an integrative approach to programme theory construction (Chen, 1990, pp. 11-12). It combined stakeholder interviews, review of documentation such as the teacher manual for the programme (Barrett, 2012), evaluators' knowledge of cognitive behavioural therapy, and research on and evaluation of the implementation of new programmes in school contexts. The purpose of the programme theory was to show how My Friends Youth was intended 
to work, the conditions that need to be in place for a successful intervention, and what needed to happen for the programme to achieve its short-term outcomes in supporting young people to build their resilience.

Issues identified by teachers interviewed in the scoping phase were included in the programme theory: the quality of the training, teacher confidence, and interaction with other school-based initiatives. However, the theory of change was not intended to describe diverse stakeholder values, and it is possible it privileged the primary intended users' understanding of the programme. It was not shared widely with other stakeholders during the evaluation.

In the educative values-engaged approach, the evaluand is a matter for discussion with as many stakeholder groups as possible (Greene, 2005a). This approach values programme theory construction as a strategy to "help various stakeholders articulate their own assumptions, perspectives, interests and values" (Greene et al., 2006, p. 59). It also serves the purpose of including diverse stakeholders in a conversation about programme quality (Greene, interviewed in Lopez, 2005 , p. 1). The principles of inclusion (of many different people), dialogue (through interviews and discussions) and deliberation (surfacing different positions, inconsistencies and commonalities) are visible in this approach. These principles have their roots in House and Howe's deliberative democratic approach (House \& Howe, 1999), which may lead to the production of multiple programme theories for the same evaluand.

An educative values-engaged approach to the My FRIENDS Youth evaluation would have included more teachers and the two regional facilitators in the development of the theory of change. Discussions would have surfaced what they thought the programme was intended to do, what they wanted it to lead to for themselves and their students, and what sorts of conditions would be necessary to 
support their facilitation of the programme. Evaluators would also have considered strategies to include the voices of parents and students in this process.

\section{Evaluation questions}

Programme theory is one way that evaluators decide on which aspects of an evaluand to focus attention on. Another important aspect is the generation and selection of evaluation questions. In the My FRIENDS Youth evaluation, an initial list of evaluation questions was included in the RFP. The scoping phase interviews and subsequent development of the theory of change highlighted key areas for the evaluation to focus on, and suggested that some of the evaluation questions signalled in the RFP needed to be adjusted (NZCER, 2013b). In particular, a trial of a clinical measure of anxiety revealed challenges with using it in relation to a universal programme, and after negotiation with the Ministry of Education stakeholders the evaluation team agreed to focus on wellbeing using a more appropriate tool. This necessitated a change to the evaluation question about student outcomes. We made minor adjustments to the wording of other questions, and a question was added to focus on one particular outcome for teachers.

The final agreed evaluation questions are shown in Figure 1. These questions focus on implementation of the programme, its relevance to the New Zealand context, and progress towards short-term outcomes, particularly improvements in wellbeing for students, and teacher confidence in supporting students. Particular attention is given to the impact of the programme for priority learner groups-Māori students, Pasifika students, students with special education needs, and students from low socioeconomic backgrounds (MacDonald et al., 2015). These final evaluation questions were agreed with the Ministry of Education stakeholders as the primary intended users. 
Figure 1: Final agreed evaluation questions for the MY FRIENDS Youth evaluation

1. Has My FRIENDS Youth increased wellbeing (as measured through Wellbeing@School) in young people?

2. How does My FRIENDS Youth impact on priority learners?

3. Was My FRIENDS Youth implemented as intended?

4. Is My FRIENDS Youth relevant in the New Zealand cultural and educational context?

5. What are the My FRIENDS Youth programme factors that support and hinder adherence, satisfaction and acceptability of the programme?

6. Does the My FRIENDS Youth programme support teachers to manage classroom conversations about wellbeing?

(MacDonald et al., 2015, p.3)

Taking an educative values-engaged approach, the evaluator aims for evaluation questions that reflect diverse stakeholder perspectives (Greene et al., 2006). At first glance the questions asked in the My FRIENDS Youth evaluation with their focus on both students and teachers could be seen as an attempt to do this. However, fundamentally these are still the policy questions asked by the funders of the programme, appropriate for their position as primary intended users in a utilisation-focused evaluation. Greene, Millett and Hopson (2004, p. 101) suggest that these types of questions generate "conventional evaluative knowledge" rather than "authentic knowledge". Both kinds of knowledge are deemed valuable in a values-engaged approach, but in addition to understanding how well participants respond to a programme, authentic knowledge offers "an understanding of how well a program responds to the nitty-gritty realities of participants' daily lives" (Greene et al., 2004, p. 101). Evaluation questions in an educative values-engaged evaluation would also bring explicit attention to social justice and equity issues. 
Considering these two important focuses for evaluation questions in an educative values-engaged approach-framing the evaluation to gain authentic knowledge, and giving explicit attention to social justice and equity issues — we suggest some questions that could have framed an educative values-engaged evaluation of My FRIENDS Youth (see Figure 2). These could be in addition to the evaluation questions addressed in the existing evaluation, and would be a good starting point for a discussion with stakeholders to prioritise information needs.

Figure 2: Evaluation questions that might have been generated from an educative valuesengaged perspective

1. How and to what extent do students enhance their skills and knowledge about resilience because of participation in the programme? Are outcomes better for some students than others?

2. In what ways and to what extent does the My FRIENDS Youth programme meet the needs of young people and their families in each community?

3. In particular, how well are the needs of Màori and Pasifika students recognised and met in the design and implementation of My FRIENDS Youth?

4. In what ways and to what extent does the My FRIENDS Youth programme meet the needs of teachers?

5. How well prepared and supported are teachers to implement the My FRIENDS Youth programme with high quality?

6. What are parent and whānau perceptions of My FRIENDS Youth?

7. Can everyone access the programme?

8. How does the programme respond to the lived experiences of diverse students? How well does it show up in their lives?

(These questions are informed by those posed in Greene et al., 2006; Greene, 2005b; Kushner, cited in Hall et al., 2012) 


\section{Methods}

The My FRIENDS Youth evaluation used a component mixed methods design, where "methods remain distinctly identifiable throughout the study" (Greene, 2007, p. 121). Mixed methods or multi-methods are increasingly important in educational evaluations. Given the diversity of evaluation questions, the different contexts and political agendas and the domain-specific needs of stakeholders, it is important to utilise the most appropriate approach for the research imperative (Johnson, 2015), given such evaluations are often undertaken in authentic real-world settings (Mertens \& Tarsilla, 2015).

The aim of the current evaluation was to gain a broad, comprehensive understanding of the programme, such that the use of qualitative and quantitative methods had a "complementarity purpose" (Greene, 2007, p. 101). Data comprised Wellbeing@School surveys (NZCER, n.d.) completed by over 2,000 students before and after the programme, a post-programme survey of 31 teachers ${ }^{1}$, individual interviews with 17 school staff, and group interviews involving 160 students at five diverse secondary schools.

The evaluation design foregrounded the collection of data about students' experiences of My FRIENDS Youth. More than 2,400 students from 22 of the 26 schools $^{2}$ responded to three statements about My FRIENDS Youth in a post-programme survey:

- I am using strategies that I learnt from the My FRIENDS Youth programme.

- The My FRIENDS Youth programme was worth doing.

- What I have learnt from the My FRIENDS Youth programme will be useful for me in the future. (MacDonald et al., 2015)

\footnotetext{
1 All teachers facilitating the programme were invited to complete a survey.

2 All 26 schools were invited to ask their students to complete surveys. Data were analysed at the school level and returned to schools.
} 
Responses to these statements were analysed by gender and ethnicity. A more in-depth and nuanced student perspective was gained from the views of 160 students who participated in group interviews (Bourke \& MacDonald, 2016). These interviews covered topics such as what students thought the programme was trying to do, what they had learned from it, things they liked best and least about the programme, and advice to teachers facilitating the programme.

The evaluation team visited five schools as one case study. Within an evaluation, especially where there are multiple sites within a single case, the case boundaries need to be clearly defined (Stake, 1995, 2008). Stake (1995) identifies three kinds of case study: intrinsic, instrumental and collective. An intrinsic case study is used when the researcher is interested in understanding a specific case itself, but an instrumental case study is used when the evaluator is primarily interested in understanding something more general than the particular case. In this evaluation we used an instrumental case study as "we have a research question, a puzzlement, a need for general understanding, and feel that we may get insight into the question by studying a particular case" (Stake, 1995, p. 3).

Teachers in the five schools were asked to offer all students the opportunity to participate in a group interview, but to particularly consider the inclusion of: students from the main cultural groups at the school, boys and girls, students with special educational needs who could participate, and students who identify as Māori or Pasifika. Classroom observations were undertaken in three of the schools where education postgraduate students contributed to fieldwork with the evaluators. These observations were not originally built into the design, because of resource constraints, but contributed to the overall understanding of how the programme was being facilitated by teachers and engaged with by students. Teachers and students were asked 
about parental involvement, but parents were not directly included in any evaluation activities.

An educative values-engaged evaluation of My FRIENDS Youth would probably employ many of the methods used in the current evaluation, using a mixed methods inquiry. Critically, though, the difference would be in the emphasis. For example, there would have been increased observations at the classroom and school level, and interviews with the parents of the students involved. Understanding context is central to the educative values-engaged approach, so "a values-engaged approach to evaluation happens close-up, in and around the setting of the evaluand" (Greene, 2005b, p. 12). To address the proposed evaluation questions (Figure 2), an educative values-engaged approach would also have given greater weight to what parents valued in relation to their child's resilience and wellbeing, and whether the programme was meeting their needs.

\section{Analysis and reporting}

Consistent with the component design, in the My FRIENDS Youth evaluation, data collected from different methods were analysed separately, and combined during interpretation and conclusion (Greene, 2007, p. 121). The main substantive chapters discussed student outcomes, teacher experiences, and the degree of fit with the New Zealand context (MacDonald et al., 2015). The qualitative data from the five schools were analysed thematically as one case, and integrated throughout the report. School-level narratives were not analysed or reported as distinct case studies.

In keeping with the utilisation-focused evaluation approach, reporting focused on the primary intended users, meeting their information needs and timeframes. They were the only stakeholders that commented on the draft report, the structure of which had been discussed with them in advance. Individual schools were provided 
with their own student data reporting on wellbeing, and a summary of the full evaluation report was written for a school audience.

Taking an educative values-engaged approach, each school is likely to be analysed and reported as a case, highlighting contextual factors and diversity of experience. An ethical consideration in this approach might be that each school is identified, and this would need to be balanced against the proposed benefits of a school understanding their implementation of the programme in more depth. A characteristic of the approach is "exploration of learning experiences and outcomes for all individuals served by the program, not relying on an average or aggregate as adequate representation" (Greene et al., 2006, p. 69). Consistent with the educative emphasis, these cases would be discussed and shared with participants in each school context, and allow for an engagement with the evaluation data for their own reflection and action (Greene, 2005a). This returns to the idea of the engagement of a wide range of stakeholders throughout the evaluation, discussed early in this article.

\section{Expanding the evaluation imagination}

Alkin and Christie (2005b) note the similarities in approaches proposed by different theorists responding to the same evaluand, but suggest that "one theorist can generally agree with another's procedures and actions, but the intentions behind the actions are the basis for theoretical nuances that make a difference" (p. 118). This article has explored both the similarities and theoretical nuances of two hybrid approaches in relation to evaluation of the My FRIENDS Youth programme. These are summarised in Figure 3. 
Figure 3: Two theoretical approaches considered in relation to evaluating My FRIENDS Youth

\begin{tabular}{|c|c|c|c|}
\hline & $\begin{array}{l}\text { Theory-based and } \\
\text { utilisation-focused }\end{array}$ & $\begin{array}{l}\text { Educative } \\
\text { values-engaged }\end{array}$ & $\begin{array}{l}\text { Consistent across } \\
\text { both approaches }\end{array}$ \\
\hline $\begin{array}{l}\text { Main } \\
\text { orientation }\end{array}$ & Use and decision-making & Social justice & \\
\hline $\begin{array}{l}\text { Stakeholder } \\
\text { engagement }\end{array}$ & $\begin{array}{l}\text { Focus is on primary intended } \\
\text { users - in this evaluation, the } \\
\text { funder }\end{array}$ & $\begin{array}{l}\text { Focus is on inclusion } \\
\text { of wide range of } \\
\text { stakeholders }\end{array}$ & $\begin{array}{l}\text { Stakeholder } \\
\text { engagement critical } \\
\text { to both approaches }\end{array}$ \\
\hline $\begin{array}{l}\text { Programme } \\
\text { theory }\end{array}$ & $\begin{array}{l}\text { One version. Some engagement } \\
\text { with stakeholders but focus } \\
\text { likely to be on primary intended } \\
\text { users' understanding of the } \\
\text { programme }\end{array}$ & $\begin{array}{l}\text { Potentially multiple } \\
\text { versions. Diverse } \\
\text { stakeholders included } \\
\text { in development, with a } \\
\text { focus on values }\end{array}$ & $\begin{array}{l}\text { Frames the evaluation } \\
\text { in both approaches }\end{array}$ \\
\hline $\begin{array}{l}\text { Evaluation } \\
\text { questions }\end{array}$ & $\begin{array}{l}\text { Questions that support } \\
\text { information needs of primary } \\
\text { intended users }\end{array}$ & $\begin{array}{l}\text { Questions that value } \\
\text { diversity, context, and } \\
\text { lived experiences of the } \\
\text { programme }\end{array}$ & $\begin{array}{l}\text { Negotiated and } \\
\text { agreed early in the } \\
\text { evaluation in both } \\
\text { approaches }\end{array}$ \\
\hline Methods & $\begin{array}{l}\text { Focus is on breadth to } \\
\text { understand the programme as } \\
\text { a whole. Depth from qualitative } \\
\text { data methods to the extent that } \\
\text { budget allowed }\end{array}$ & $\begin{array}{l}\text { In-depth site visits to } \\
\text { see the programme } \\
\text { in action in different } \\
\text { contexts. Data } \\
\text { collected from diverse } \\
\text { stakeholders }\end{array}$ & $\begin{array}{l}\text { Mixed methods, } \\
\text { selected for fit } \\
\text { with evaluand and } \\
\text { evaluation questions } \\
\text { in both approaches }\end{array}$ \\
\hline $\begin{array}{l}\text { Analysis and } \\
\text { reporting }\end{array}$ & $\begin{array}{l}\text { Requires overall judgement } \\
\text { about the programme as a } \\
\text { whole to address evaluation } \\
\text { questions. Primary intended } \\
\text { users as first audience for } \\
\text { reporting }\end{array}$ & $\begin{array}{l}\text { Analysis and reporting } \\
\text { focuses on school- } \\
\text { level cases. Diverse } \\
\text { stakeholders likely to } \\
\text { contribute to sense- } \\
\text { making and be key } \\
\text { audience for reporting }\end{array}$ & $\begin{array}{l}\text { Integration of mixed } \\
\text { methods data in both } \\
\text { approaches }\end{array}$ \\
\hline
\end{tabular}

All evaluations have their own unique blend of theory and practice, and require trade-offs between evaluation purpose, stakeholder needs, degree of certainty required in conclusions, budget, and time available (Davidson, 2000; Shadish, 1998). However, knowledge of different evaluation approaches gives evaluators options and alternatives, and opens up the conversations with their stakeholders to determine what approach is most likely to meet the needs of the funding body, while also contributing to the practices in the field. 
In the evaluation of the My FRIENDS Youth universal schoolbased resilience programme, funded as part of a high profile crossagency project, the funder's information needs and evaluation questions were foregrounded, consistent with their position as primary intended users in a utilisation-focused evaluation. This meant that the evaluation could make judgements about the implementation and short-term outcomes of the programme as a whole, across all schools. Although the evaluation kept students and teachers in focus and sought to understand how the programme was implemented in diverse contexts, it did minimise the possibility of a rich and deep understanding of the programme implementation in each school setting. There were also potential ethical dilemmas arising from the funder but not the participants contributing to decisions about evaluation design. In an international evaluation context, Williams (2016) draws our attention to evaluators using methodological approaches that might be "ethical" but run counter to the needs of participants and have unintended consequences. Williams argues that "often more attention is paid to logistical or methodological dilemmas, with ethics taking a back seat in informing decision-making by evaluators" (p. 536).

An educative values-engaged approach would have focused on involving a more diverse range of stakeholders throughout the evaluation, and would have foregrounded what teachers, students, parents and policy makers valued in relation to a resilience and wellbeing programme. This approach would have highlighted the programme in action in different contexts, gaining a richer picture of school-level practice, but could have lost an understanding of the outcomes from the programme as a whole. In addition, these aspects of an educative values-engaged approach are potentially time-consuming and expensive, and would have required negotiation and agreement with the funding body about potential trade-offs. 
One important consideration is therefore whether evaluation approaches are fit for purpose, given "every theory of practice is likely to be more effective in some settings than in others" (Donaldson $\&$ Lipsey, 2006, p. 62). It is also conceivable that a hybrid or "eclectic evaluation approach" (Stufflebeam \& Shinkfield, 2007, p. 229) could frame an evaluation, drawing ideas from a diverse range of approaches. This could be particularly pertinent in a utilisation-focused evaluation approach, where use by primary intended users is the main consideration but no other aspects of evaluation practice are prescribed. As already described, both the evaluation approaches discussed in this article are already hybrids - the actual evaluation (theory-based and utilisation-focused) and the educative values-engaged approach (which draws on responsive evaluation, deliberative democratic evaluation, and evaluation as an educational endeavour).

Knowledge of evaluation approaches gives evaluators more to draw on in considering what could be included in an eclectic approach. If we were to re-negotiate the My FRIENDS Youth evaluation and take a different approach, the evaluation team could consider which aspects of the educative values-engaged approach were viable additions to the evaluation plan. These might include, for example, explicitly surfacing values in the programme theory development, generating a broader range of evaluation questions, and ensuring that a wider group of stakeholders helped frame the evaluation. Conversations about these aspects with the primary intended users may have enhanced evaluation practice, while remaining a theory-based utilisation-focused evaluation at its core.

\section{Conclusion}

This article set out to consider whether and how an understanding of different evaluation theories or approaches contributes to evaluation practice. It has discussed one alternative approach to a 
recent evaluation and considered the "theoretical nuances" (Alkin $\&$ Christie, 2005b) in these approaches. By reflecting on these nuances, we as evaluators can envisage different ways of doing things, can better think through the intended and unintended consequences of our practice, and can view evaluation and evaluands through multiple lenses. Without evaluation theory, evaluation practice risks being a "collection of methods and techniques without guiding principles for their application" (Shadish, 1998, p. 13). These guiding principles are an important contribution to evaluation practice, ensuring evaluators do not rely on habitual or intuitive decisions (Schwandt, 2008). In order to open up the "evaluation imagination" (Schwandt, 2008), it is essential that as well as having knowledge of multiple and diverse evaluation approaches, we reflect on our choice of approach in practice.

This article began by acknowledging reflective practice as one of four competency domains for evaluators in Aotearoa New Zealand. A second competency domain is systematic evaluative inquiry, defined as "a demonstrated understanding of the knowledge base informing the discipline and practice of evaluation", including a range of evaluation theories, approaches and models (Aotearoa New Zealand Evaluation Association, 2011, p. 13). By discussing how evaluation theories and approaches shaped practice in one evaluation, and juxtaposing a potential alternative, we are both widening our evaluation imagination and showing two of the four Aotearoa New Zealand Evaluation Association competencies in action.

\section{Acknowledgements}

This evaluation was funded by the Ministry of Education, and undertaken as part of a research partnership with the New Zealand Council for Educational Research and the Faculty of Education, Victoria University of Wellington. The findings and views reported 
in this article are those of the authors and should not be attributed to the Ministry of Education.

Jo MacDonald, NZCER, jo.macdonald@nzcer.org.nz

Roseanna Bourke, Massey University, r.bourke@massey.ac.nz

\section{References}

Alkin, M. C. (2013). Comparing evaluation points of view. In M. C. Alkin (Ed.), Evaluation roots: A wider perspective of theorists' views and influences (2nd ed., pp. 3-10). Thousand Oaks, CA: Sage.

Alkin, M. C., \& Christie, C. A. (2005a). Theorists' models in action. New Directions for Evaluation, 106(Summer).

Alkin, M. C., \& Christie, C. A. (2005b). Unraveling theorists' evaluation reality. New Directions for Evaluation, 106(Summer), 111-128. doi: $10.1002 /$ ev.155

Aotearoa New Zealand Evaluation Association. (2011). Evaluator competencies. Retrieved from http://www.anzea.org.nz/wp-content/ uploads/2013/05/110801_anzea_evaluator_competencies_final.pdf

Barrett, P. (2012). My FRIENDS Youth resilience program: Group leaders' manual for youth. Brisbane, QLD: Barrett Research Resources Pty Ltd.

Bourke, R., \& MacDonald, J. (2016). Creating a space for student voice in an educational evaluation. International Journal of Research \& Method in Education, 1-13. doi: 10.1080/1743727x.2016.1256983

Chen, H.-T. (1990). Issues in constructing program theory. New Directions for Evaluation, 47(Fall), 7-18. doi: 10.1002/ev.1551

Christie, C. A., \& Alkin, M. C. (2013). An evaluation theory tree. In M. C. Alkin (Ed.), Evaluation roots: A wider perspective of theorists' views and influences (2nd ed., pp. 11-57). Thousand Oaks, CA: Sage.

Cronbach, L. J., Ambron, S. R., Dornbusch, S. M., Hess, R. D., Hornik, R. C., Phillips, D.C., . . Weiner, S. S. (1980). Toward reform of program evaluation. San Francisco, CA: Jossey-Bass. 
Davidson, E. J. (2000). Ascertaining causality in theory-based evaluation. New Directions for Evaluation, 87(Fall), 17-26. doi: 10.1002/ev.1178

Donaldson, S. I., \& Lipsey, M. W. (2006). Roles for theory in contemporary evaluation practice: Developing practical knowledge. In I. F. Shaw, J. Greene \& M. M. Mark (Eds.), The Sage handbook of evaluation (pp. 56-75). Beverly Hills, CA: Sage Publications.

Greene, J. C. (2005a). A value-engaged approach for evaluating the Bunche-Da Vinci Learning Academy. New Directions for Evaluation, 106(Summer), 27-45. doi: 10.1002/ev.150

Greene, J. C. (2005b). Evaluators as stewards of the public good. In S. Hood, R. Hopson, \& H. Frierson (Eds.), The role of culture and cultural context: A mandate for inclusion, the discovery of truth and understanding in evaluative theory and practice (pp. 7-20). Greenwich, CT: Information Age Publishing.

Greene, J. C. (2007). Mixed methods in social inquiry. San Francisco, CA: Jossey-Bass.

Greene, J. C. (2013). Making the world a better place through evaluation. In M. C. Alkin (Ed.), Evaluation roots: A wider perspective of theorists' views and influences (2nd ed., pp. 208-217). Thousand Oaks, CA: Sage.

Greene, J. C., Millett, R. A., \& Hopson, R. K. (2004). Evaluation as a democratizing practice. In M. T. Braverman, N. A. Constatine, \& J. K. Slater (Eds.), Foundations and evaluation: Contexts and practices for effective philanthropy (pp. 96-118). San Francisco, CA: Jossey-Bass.

Greene, J. C., DeStefano, L., Burgon, H., \& Hall, J. (2006). An educative, values-engaged approach to evaluating STEM educational programs. New Directions for Evaluation, 109(Spring), 53-71.

Hall, J. N., Ahn, J., \& Greene, J. C. (2012). Values engagement in evaluation: Ideas, illustrations, and implications. American Journal of Evaluation, 33(2), 195-207. doi: 10.1177/1098214011422592

Hansen, H. F. (2005). Choosing evaluation models: A discussion on evaluation design. Evaluation, 11(4), 447-462. doi: $10.1177 / 1356389005060265$ 
House, E. R., \& Howe, K. R. (1999). Values in evaluation and social research. Thousand Oaks, CA: Sage.

International Development Research Centre. (2012). Identifying the intended user(s) and use(s) of an evaluation. Retrieved from http://idl-bnc.idrc.ca/dspace/bitstream/10625/47278/1/133624.pdf

Johnson, B. R. (2015). Conclusion: Towards an inclusive and defensible multimethod and mixed method science. In A. Hesse-Biber \& B. R. Johnson (Eds.), The Oxford handbook of multimethod and mixed methods research inquiry (pp. 688-707). New York, NY: Oxford University Press.

Leviton, L. C. (2015). Evaluation practice and theory: Up and down the ladder of abstraction. American Journal of Evaluation, 36(2), 238-242. doi: $10.1177 / 1098214015573070$

Lopez, M. E. (2005). A conversation with Jennifer Greene.

The Evaluation Exchange, XI(3). Retrieved from http://www.hfrp.org/evaluation/the-evaluation-exchange/issue-archive/ democratic-evaluation/a-conversation-with-jennifer-greene

MacDonald, J., Bourke, R., Berg, M., \& Burgon, J. (2015). My FRIENDS Youth final evaluation report. Wellington: Ministry of Education.

Mertens, D., \& Tarsilla, M. (2015). Mixed methods evaluation. In A. Hesse-Biber \& B. R. Johnson (Eds.), The Oxford handbook of multimethod and mixed methods research inquiry (pp. 426-446). New York, NY: Oxford University Press.

Ministry of Education. (2013). Request for proposals for the evaluation of the Ministry of Education trial of My FRIENDS Youth. Wellington: Author.

Ministry of Health. (2016). Youth Mental Health project initiatives. Retrieved 20 April 2016, from http://www.health.govt.nz/ourwork/mental-health-and-addictions/youth-mental-health-project/ youth-mental-health-project-initiatives

NZCER. (2013a). Evaluation plan for FRIENDS Youth pilot programme (May). Unpublished. 
NZCER. (2013b). Evaluation plan for FRIENDS Youth pilot programme (revised, October). Unpublished.

NZCER. (n.d.).Wellbeing@School. Retrieved 3 June 2016, from http://www.nzcer.org.nz/tests/wellbeingschool

Patton, M. Q. (2003). Utilization-focused evaluation. In T. Kellaghan \& D. L. Stufflebeam (Eds.), International handbook of educational evaluation (pp. 223-243). Dordrecht, The Netherlands: Kluwer Academic.

Patton, M. Q. (2008). Utilization-focused evaluation (4th ed.). Los Angeles, CA: Sage.

Patton, M. Q. (2013). The roots of utilization-focused evaluation. In M. C. Alkin (Ed.), Evaluation roots: A wider perspective of theorists' views and influences (2nd ed., pp. 293-303). Thousand Oaks, CA: Sage.

Patton, M. Q. (2015). The sociological roots of utilization-focused evaluation. The American Sociologist, 46(4), 457-462. doi: 10.1007/s12108-015-9275-8

Rogers, P. J. (2007). Theory-based evaluation: Reflections 10 years on. New Directions for Evaluation, 114(Summer), 63-81. doi: 10.1002/ev.225

Rogers, P. J., Petrosino, A., Huebner, T. A., \& Hacsi, T. A. (2000). Program theory evaluation: Practice, promise, and problems. New Directions for Evaluation, 87(Fall), 5-13. doi: 10.1002/ev.1177

Schwandt, T. A. (2008). The relevance of practical knowledge traditions to evaluation practice. In N. L. Smith \& P. R. Brandon (Eds.), Fundamental issues in evaluation. New York, NY: The Guilford Press.

Schwandt, T. A. (2013). On the mutually informing relationship between practice and theory in evaluation. American Journal of Evaluation. [Advance online publication]. doi: 10.1177/1098214013503703

Shadish, W. R. (1998). Evaluation theory is who we are. American Journal of Evaluation, 19(1), 1-19. doi: 10.1177/109821409801900102

Stake, R. E. (1995). The art of case study research. Thousand Oaks, CA: Sage.

Stake, R. E. (2008). Qualitative case study. In N. K. Denzin \& Y. S. Lincoln (Eds.), Strategies of qualitative inquiry (3rd ed., pp. 119-150). Thousand Oaks, CA: Sage. 
Stufflebeam, D. L., \& Shinkfield, A. J. (2007). Evaluation theory, models and applications. San Francisco, CA: Jossey-Bass.

Weiss, C. H. (1997). Theory-based evaluation: Past, present, and future. New Directions for Evaluation, 76(Winter), 41-55. doi: 10.1002/ev.1086

Williams, L. G. (2016). Ethics in international development evaluation and research: What is the problem, why does it matter and what can we do about it? Journal of Development Effectiveness, 8(4), 535-552. doi: 10.1080/19439342.2016.1244700 